[Agr. Biol. Chem., Vol. 35, No. 12, p. 1891 1898, 1971]

\title{
Studies of Hemicellulolytic Enzymes of Bacillus subtilis
}

\author{
Part I. Purification, Crystallization and Some Properties \\ of Arabinogalactanase
}

\author{
By Shigenori Emi, Juichiro Fukumoto and Takehiko Yamamoto \\ Faculty of Science, Osaka City University, Sumiyoshi-ku, Osaka \\ Received May 19, 1971
}

\begin{abstract}
Many strains of Bacillus subtilis were found to secrete several hemicellulolytic enzymes such as arabinoxylanase, galactomannanase, arabinogalactanase, etc. Chemical and enzymatic properties of certain strains of the bacterium were comparatively investigated. An arabinogalactanase was purified and obtained in a crystalline state. Its molecular weight and isoelectric point were estimated to be $3.7 \times 10^{4}$ and 8.39 , respectively. The enzyme showed an optimal $\mathrm{pH}$ for reactions at 6.0 , and was stable in a $\mathrm{pH}$ range of 5.0 to 9.5 at $30^{\circ} \mathrm{C}$. It required no metallic ions for its activity and hydrolyzed soybean arabinogalactan, forming galactobiose as the main product. No liberation of arabinose was observed in the hydrolysate. Also, the enzyme did not attack coffee bean arabinogalactan. Some implications of the experimental results are discussed.
\end{abstract}

Plant cell wall polysaccharides other than starch, cellulose and pectic substances have been raferred to as hemicelluloses. However, very few of their chemical structures have been clarified. Obviously enzymes are significant in the study of the chemical structures of such substances as above.

Many strains of a bacterium belonging to Bacillus subtilis produced enzymes, inducibly or constitutively, which attack hemicelluloses, e.g. arabinoxylan, galactomannan, and arabinogalactan. Thus, a study was undertaken to clarify the enzymatic nature of those hemicellulolytic enzymes with special reference to strains of the bacterium which secrete enzymes.

The present paper deals with purification of arabinogalactanase from a certain strain of Bacillus subtilis and some chemical and enzymatic properties of the purified enzyme. Experimental results are also discussed.

\section{MATERIALS AND METHODS}

1. The bacterial strain used, its culture method and preliminary treatment of the culture filtrate for purification of the enzyme. A strain of liquefying $\alpha$-amylase producing Bacillus subtilis, K-50, which had been maintained in our laboratory, was used throughout the present work. The bacterium was cultured by the shaking method at $37^{\circ} \mathrm{C}$ in a medium containing $5.00^{\circ}$ soybean cake extract (boiled for one hour with twenty volumes of $\left.0.40^{\circ} \mathrm{NaOH}\right), 3.0^{\circ} \mathrm{o}$ dextrin, $1.20^{\circ}$ $\left(\mathrm{NH}_{4}\right)_{2} \mathrm{HPO}_{4}, 0.050_{0} \mathrm{CaCl}_{2}$ and $0.020_{0}$ each of $\mathrm{MgSO}_{4}$. $7 \mathrm{H}_{2} \mathrm{O}$ and $\mathrm{KCl}$, pH 7.2. After forty-five hours at $37^{\circ} \mathrm{C}$, the culture was centrifuged and solid ammonium sulfate was added to the supernatant in 0.45 saturation. The resulting precipitate was dissolved in about four volumes of water, then after adjusting the $\mathrm{pH}$ to 7.0 with a sodium hydroxide solution, calcium chloride was added to the solution in equivalence to the $\mathrm{SO}_{4}{ }^{2-}$ present. The resulting precipitate was removed by centrifugation, then two volumes of cold isopropanol were added to the supernatant. After standing overnight in the cold, the precipitated enzyme was collected by centrifugation and dialyzed against a changing solution of $M / 500$ calcium acetate, pH 7.0. The dialyzed enzyme was then passed through a column of Duolite $\mathrm{A}-2$ equilibrated with $\mathrm{M} / 20$ acetate buffer, pH 5.8. The decolored enzyme solution was subjected to purification as described below. 
2. Enzyme activity assay. One $\mathrm{ml}$ of enzyme at $40^{\circ} \mathrm{C}$ was added to $4 \mathrm{ml}$ of substrate $(0.5 \circ \%$, buffered with $\mathrm{M} / 50$ acetate, $\mathrm{pH} 6.0$ ); after five minutes the reducing sugar formed was determined as galactose by the method of Shaffer-Somogyi.11 One unit of enzyme activity was defined as the enzyme quantity that produced reducing sugars equivalent to $1.0 \mu$ mole of galactose per min under the above conditions. Specific enzyme activity was tentatively expressed as the value obtained by dividing the enzyme activity per $\mathrm{ml}$ by the absorbancy at $280 \mathrm{~m} \mu$ per $\mathrm{cm}$ of enzyme solution.

3. Substrate used. Soybean arabinogalactan was prepared according to the method of Morita. ${ }^{2}$ Defatted soybean flour $(200 \mathrm{~g})$ was suspended in ten volumes of $0.1 \mathrm{~N}$ sodium hydroxide solution with stirring at $25^{\circ} \mathrm{C}$ for one hour. The mixture was then centrifuged and its precipitate was re-treated with alkali in a similar manner. After repeating this procedure two more times, the residue was mixed with 1 liter of deionized water, then it was boiled for one hour. Extraction with boiling water was repeated three times. Supernatants were combined and, after concentration to an adequate volume under reduced pressure, the concentrate was allowed to stand in the cold for three weeks. The supernatant thus obtained was mixed with two volumes of cold acetone then it was brought to dryness by washing it successively with acetone and ether. The yield of this material was $4.5 \%$ (water content, $11.20^{\circ}$ ), and hydrolysis of the material, with $1.0 \mathrm{~N}$ hydrochloric acid at $100^{\circ} \mathrm{C}$ for two hours gave $800^{\circ}$ reducing sugars as galactose. In the acid-hydrolysate, arabinose and galactose were found in a ratio of nearly one of the former to two of the latter. A trace amount of xylose was also found in the hydrolysate.

Arabinogalactan of coffee bean was prepared by the method of Wolfrom and Patin.31 Coffee beans were pulverized and successively extracted with two portions of a mixture of ethanol and benzene $(1: 2)$, ten portions of water $\left(25^{\circ} \mathrm{C}\right)$ and twenty portions of 1.00 sodium hypochlorite. The residue obtained was boiled with twenty portions of water for eight hours. After concentration to an adequate volume

1) P. A. Shaffer and M. Somogyi, J. Biol. Chem., 100, 695 (1933).

2) M. Morita, Agr. Biol. Chem., 29, 564, 626 (1965).

3) M. L. Wolfrom and D. L. Patin, J. Org. Chem., 30, 4060 (1965). under reduced pressure, the supernatant was mixed with three volumes of cold ethanol. The precipitate obtained was dried by washing it successively with ethanol and ether. The yield of arabinogalactan using this procedure was $3.0 \%$. Hydrolysis with $1.0 \mathrm{~N}$ hydrochloric acid for two hours produced arabinose and galactose in a molar ratio of about one of the former to three of the latter.

To check whether the purified arabinogalactanase preparation showed any other hemicellulolytic activities, several other hemicelluloses such as araban from beet, arabinoxylan from soybean and rice straw, galactomannan from soybean and coffee bean, glucomannan from konjak (Amorphophalus konjac) and xylan from cotton seed were used as substrates.

4. Paperchromatography. Paperchromatography was carried out by the descending method using Tôyo Roshi No. 50 as the paper and butanol: pyridine: water $(6: 4: 3, v / v)$ as the solvent. Detection of reducing sugar was made by spraying an alkaline solution of silver nitrate or aniline hydrogen phthalate on the sample.

\section{RESULTS}

\section{Purification and crystallization of the enzyme}

The crude enzyme solution obtained, described in Materials and Methods, was passed through a column of SE-Sephadex C-25 at $5^{\circ} \mathrm{C}$, which had been equilibrated with $\mathrm{M} / 50$ acetic acid-sodium acetate buffer, $\mathrm{pH} 5.8$, containing M/500 calcium acetate. Arabinogalactanase was adsorbed on the resin. After washing the column with $\mathrm{M} / 50$ acetate buffer, $\mathrm{pH} 5.8$, containing $\mathrm{M} / 500$ calcium acetate, a solution of sodium chloride containing $\mathrm{M} / 50$ acetate buffer and $\mathrm{M} / 500$ calcium acetate, $\mathrm{pH} 5.8$, was passed through the column, increasing the concentration of sodium chloride linearly from the zero to $0.5 \mathrm{M}$. As shown in Fig. 1, the enzyme was eluted from the resin with about $0.2 \mathrm{M}$ sodium chloride solution. Arabinogalactanase fractions were combined and ammonium sulfate was added at 0.6 saturation. After standing overnight in the cold, the precipitate was separated by centrifugation, then dissolved in the least quantity of $M / 500$ 


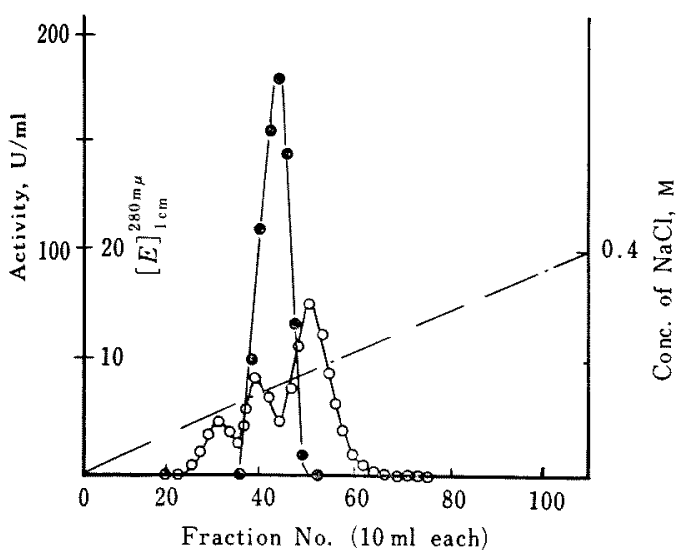

FIG. 1. SE-Sephadex C-25 Column Chromatography of Arabinogalactanase of Bacillus subtilis $\mathrm{K}-50$.

Column, $1.8 \times 44 \mathrm{~cm}, \mathrm{M} / 50$ acetate buffer containing M/500 Ca-acetate, pH 5.8; enzyme applied, $300 \mathrm{ml}$ (activity, $43.3 \mathrm{U} / \mathrm{ml} ; E_{1 \mathrm{~cm}}^{280 \mathrm{~m} \mu}, 6.3$ ); flow rate, $40 \mathrm{ml} / \mathrm{hr} ; O-O, E_{1 \mathrm{~mm}}^{280 \mathrm{~m}, \mu} ;-1$, activity; -.-. conc. of $\mathrm{NaCl}$.

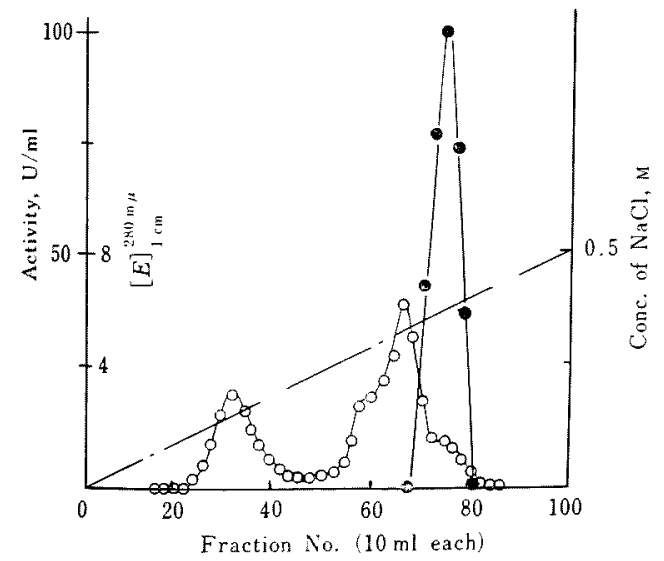

Fig. 2. DEAE-Sephadex A-50 Column Chromatography of the Arabinogalactanase of Bacillus subtilis $\mathrm{K}-50$.

Column, $2.5 \times 52 \mathrm{~cm}, \mathrm{M} / 100$ Tris-HCl buffer, $\mathrm{pH}$ 8.0, containing $M / 500$ Ca-acetate; enzyme applied, $40 \mathrm{ml}$ (activity, $250 \mathrm{U} / \mathrm{ml} ; E_{1 \mathrm{~cm} \mu}^{280 \mathrm{~m} \mu}, 30$ ); flow rate, $40 \mathrm{ml} / \mathrm{hr} ; \bigcirc-O, E_{1 \mathrm{em}}^{280 \mathrm{~m} /}-\longrightarrow$, enzyme activity; --., conc. of $\mathrm{NaCl}$. calcium acetate, and dialyzed against a changing solution of $\mathrm{m} / 500$ calcium acetate, $\mathrm{pH} 7.0$, in the cold for three days.

The dialyzed enzyme was passed through a column of DEAE-Sephadex A-50 which had been buffered with $\mathrm{M} / 100$ tris-(hydroxymethyl)-aminomethane-hydrochloric acid buffer (Tris- $\mathrm{HCl}$ ), $\mathrm{pH} 8.0$, containing $\mathrm{M} / 500$ calcium acetate. The enzyme was adsorbed on the resin and, after washing the column with $\mathrm{M} / 100$ Tris- $\mathrm{HCl}$ buffer, $\mathrm{pH} 8.0$, containing $\mathrm{M} / 500$ calcium acetate, the enzyme was desorbed with a mixture of sodium chloride and acetate buffer whose concentrations were linearly increased from zero to $0.5 \mathrm{M}(\mathrm{NaCl})$ and from zero to $\mathrm{M} / 20$ (acetate buffer, $\mathrm{pH} 5.8$ ), respectively, as shown in Fig. 2.

The enzyme purified by column chromatography on DEAE-Sephadex A-50 was precipitated with 0.6 saturation of ammonium sulfate. The precipitated enzyme was dissolved in the least amount of M/500 calcium acetate solution followed by subjecting it to gel filtration on a column of Sephadex G-75 equilibrated with $\mathrm{M} / 500$ calcium acetate, $\mathrm{pH} 7.0$.

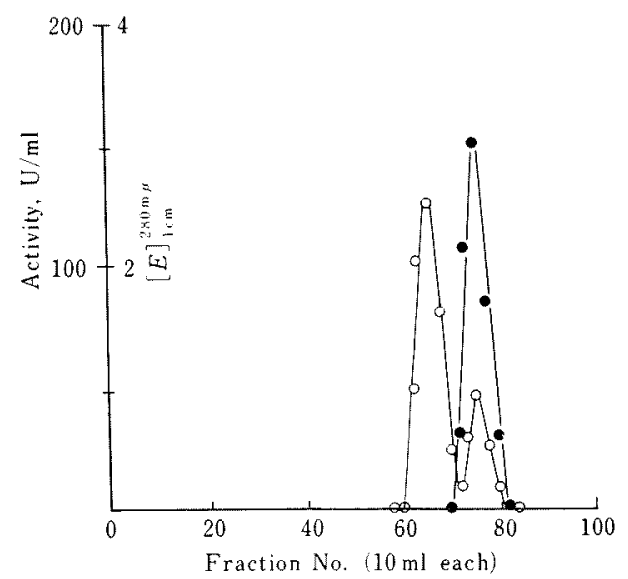

FIG. 3. Gel Filtration on a Sephadex $\mathrm{G}-75$ Column of Arabinogalactanase of Bacillus subtilis $\mathrm{K}-50$.

Column, $3 \times 114 \mathrm{~cm}, \mathrm{M} / 500$ Ca-acetate; enzyme applied, $5 \mathrm{ml}$ (activity, $1,500 \mathrm{U} / \mathrm{ml} ; E_{1 \mathrm{cml}}^{280 \mathrm{~m} / 2}, 27$ ); flow rate, $20 \mathrm{ml} / \mathrm{hr} ; \mathrm{O}-\mathrm{O}, E_{1 \mathrm{~mm}}^{280 \mathrm{~m} ;}-\mathbf{-}$, enzyme activity. 


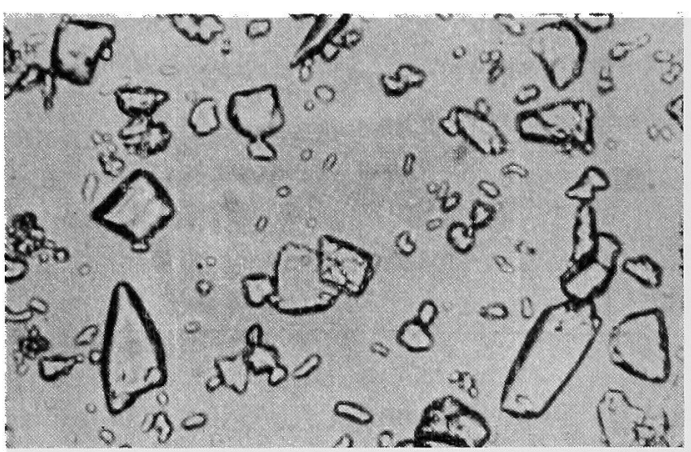

FIG. 4. Crystalline Arabinogalactanase of Bacillus subtilis $\mathrm{K}-50$.

Figure 3 shows the results, indicating that the specific activity of the enzyme was greatly increased. This highly purified enzyme solution was concentrated in a collodion bag under reduced pressure. On allowing the concentrated enzyme to stand in the cold, crystals appeared as shown in Fig. 4. In the following experiments this crystalline enzyme was used.

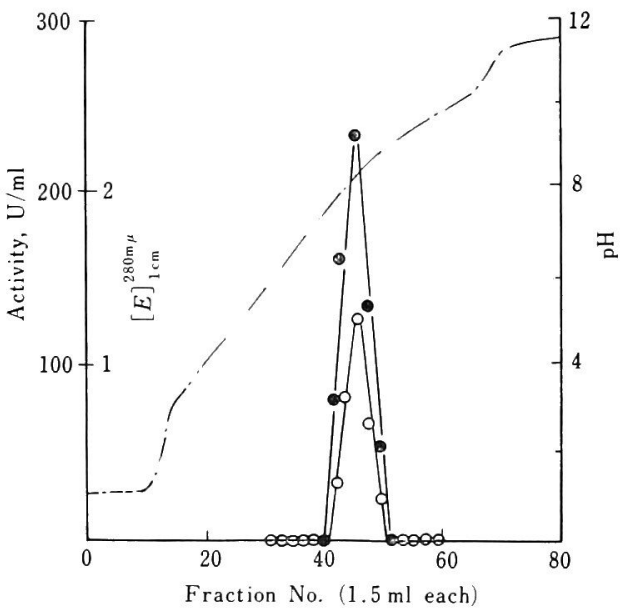

FIG. 5. Isoelectric Focusing of Crystalline Arabinogalactanase.

Column, $110 \mathrm{ml}$; enzyme applied, $2 \mathrm{ml}$ (activity,

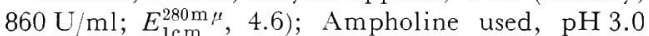
$\sim$ pH $10.0 ; 300 \mathrm{~V}, 3.5 \mathrm{~mA}$ for the first $3 \mathrm{hr}$, then $700 \mathrm{~V}, 0.8 \mathrm{~mA}$ for the last $40 \mathrm{hr}$ at $5^{\circ} \mathrm{C}$; $\mathrm{O}-\mathrm{O}$, $E_{1 \mathrm{~cm}}^{280 \mathrm{~m}} ;-1$, enzyme activity; ---, $\mathrm{pH}$.

\section{Some physical and chemical properties of crys- talline arabinogalactanase}

In Fig. 5 the results of an isoelectric focusing test with a solution of crystalline enzyme using Ampholine and sucrose as the $\mathrm{pH}$ - and density-gradients, respectively are shown. Results revealed that the isoelectric point of the enzyme was 8.39 .

Figure 6 shows the elution pattern of the enzyme from gel filtration on a Sephadex G-75 column, indicating that its elution volume is nearly the same as that of egg white lysozyme. However, ultracentrifugal analyses revealed that the sedimentation coef-

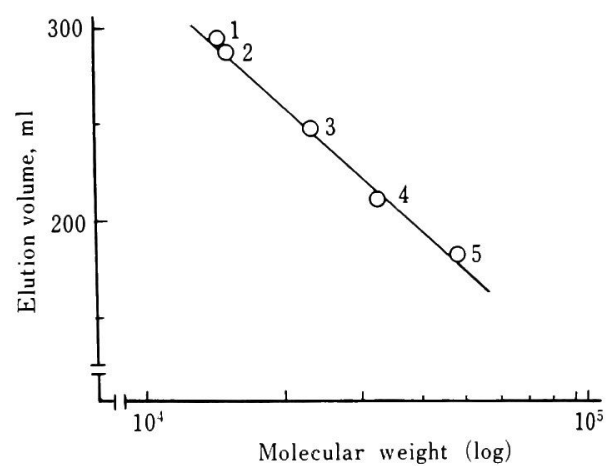

FIG. 6. Elution Volume of Arabinogalactanase by Gel Filtration on Sephadex G-75.

Column, $2.4 \times 90 \mathrm{~cm}$, equilibrated with $\mathrm{M} / 20$ acetate buffer, $\mathrm{pH} 6.0$, containing $\mathrm{M} / 500 \mathrm{Ca}$-acetate; enzyme applied, $2 \mathrm{ml}\left(E_{1 \mathrm{~cm}}^{280 \mathrm{~m} / ",} 2.0\right.$ each); molecular weights of reference enzymes; 1, egg white lysozyme $(14,307) ;{ }^{4}$ 2, arabinogalactanase; 3, alkaline protease of Bacillus subtilis var. amylosacchariticus $(22,700) ; 51$, neutral protease of the above bacterium $\left.(33,800) ;{ }^{6}\right) 5$, Bacillus subtilis' liquefying $\alpha$ amylase $(48,900) .{ }^{71}$

4) Robert E. Canfield, J. Biol. Chem., 238, 2698 (1963).

5) D. Tsuru, H. Kira, T. Yamamoto and J. Fukumoto, Agr. Biol. Chem., 31, 330 (1967).

6) D. Tsuru, H. Kira, T. Yamamoto and J. Fukumoto, ibid., 30, 1164 (1966).

7) E. H. Fischer, W. N. Sumerwell, J. M. Junge and E. A. Stein, Pro. 4 th Intern. Congr. Biochem. Vienna, 1958. Symposium 8, p. 124, Pergamon Press, 1960. 


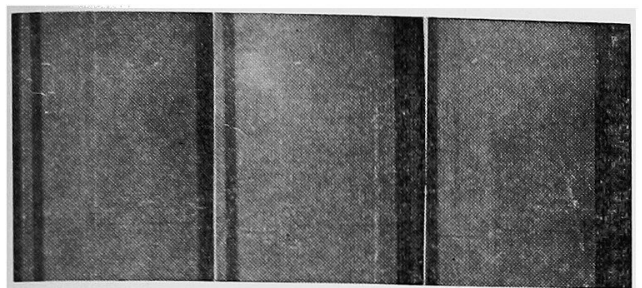

$14(\mathrm{~min})$

20

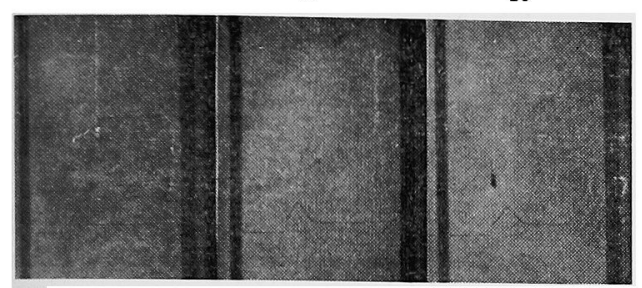

32

41

50

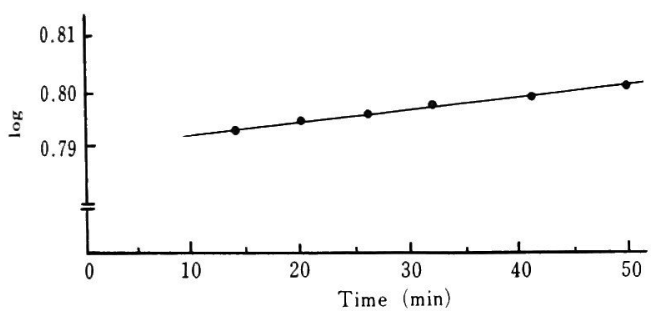

FIG. 7. Ultracentrifugal Pattern of the Arabinogalactanase of Bacillus subtilis $\mathrm{K}-50$.

Enzyme, $0.65^{\circ}$ o in $\mathrm{M} / 10$ acetate buffer, $\mathrm{pH} 6.0$; $20^{\circ} \mathrm{C}, 50,194 \mathrm{rpm} ; \mathrm{X}$, distance of boundary to axis of rotation.

ficient of the enzyme was 3.3 (Fig. 7). Its molecular weight was estimated to be $3.7 \times 10^{4}$ based on the sedimentation equilibrium method.

The ultraviolet absorption spectra of the enzyme is shown in Fig. 8. From this the number of tryptophan- and tyrosine residues per mole of enzyme were estimated to be nine and eighteen, respectively.

3. Some enzymic properties of the crystalline enzyme

The crystalline enzyme showed activity for attacking only arabinogalactan of the polysaccharides substrates tested. It had 2,420

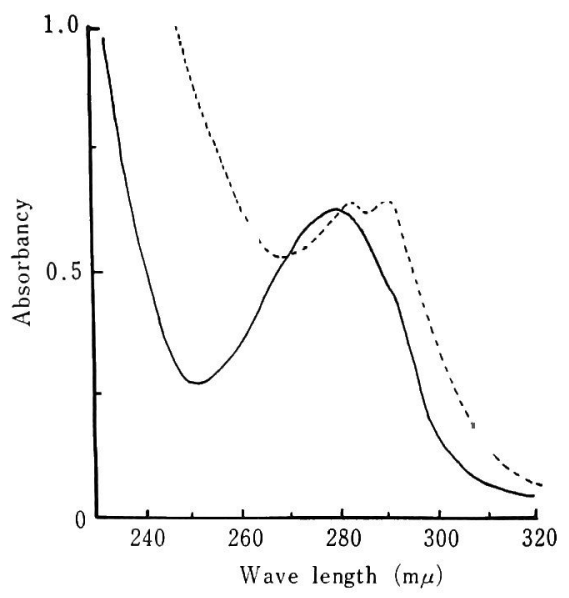

FIG. 8. Ultraviolet Absorption Spectra of Arabinogalactanase of Bacillus subtilis $\mathrm{K}-50$.

Enzyme, $111 \mathrm{U} / \mathrm{ml}$; protein $\mathrm{N}, 45.9 \mathrm{r} / \mathrm{ml}$; —, in $\mathrm{M} / 100$ phosphate buffer, $\mathrm{pH} 7.0$; ---, in $\mathrm{N} / 10$ $\mathrm{NaOH}$.

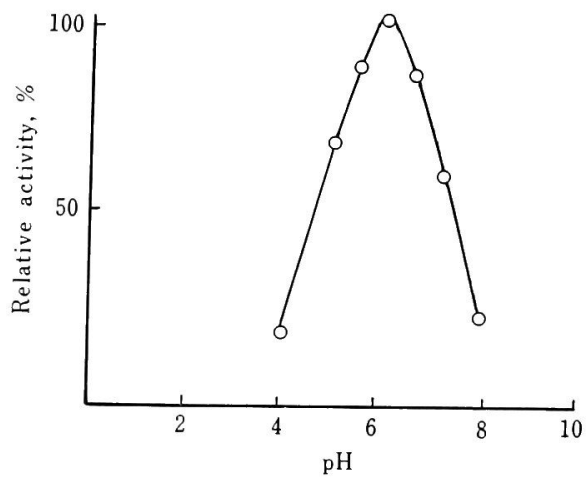

FIG. 9. pH-Activity of Arabinogalactanase.

$0.5^{\circ}$ o Soybean arabinogalactan, $40^{\circ} \mathrm{C}, 15 \mathrm{~min}$ reaction; buffer $(\mathrm{M} / 20)$ used: $\mathrm{pH} 3.0 \sim 4.0$, glycine$\mathrm{HCl} ; \mathrm{pH} 4.0 \sim 6.0$, acetate; $\mathrm{pH} 7.2 \sim 9.0$, Tris- $\mathrm{HCl}$; pH $9.0 \sim 11.0$, glycine- $\mathrm{NaOH}$.

units of activity per $\mathrm{mg}$ of nitrogen toward soybean arabinogalactan. Also, its specific activity, obtained by the method in Materials and Methods was 185 . The yield of activity recovered in the crystalline enzyme was $10 \%$ and the specific activity increased about 5,000 


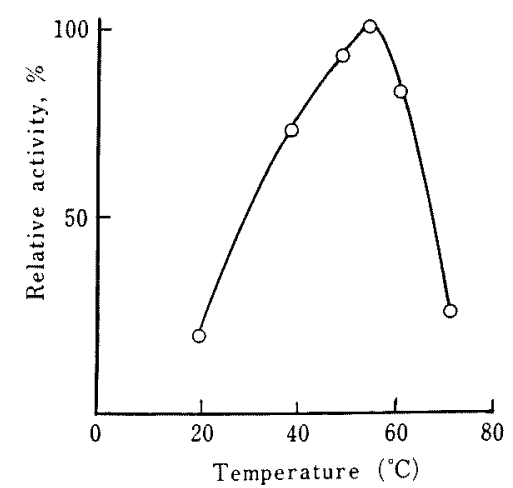

FIg. 10. Temperature-Activity of Arabinogalactanase.

$\mathrm{M} / 50$ Acetate buffer, $\mathrm{pH} 6.0,15 \mathrm{~min}$ reaction.

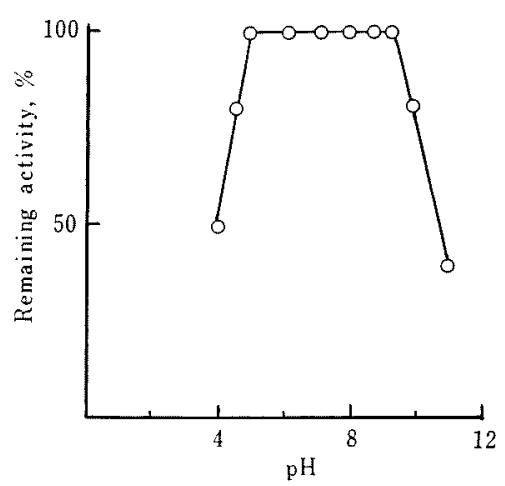

Fig. 11. pH-Stability of Arabinogalactanase.

$30^{\circ} \mathrm{C}, 24 \mathrm{hr}$ with $\mathrm{M} / 20$ buffer solution: $\mathrm{pH}$ $4.0 \sim 6.0$, acetate; $\mathrm{pH} 7.2 \sim 9.0$, Tris-HCI; $\mathrm{pH}$ $9.0 \sim 11.0$, glycine- $\mathrm{NaOH}$.

fold that of the culture filtrate.

The enzyme showed its optimal $\mathrm{pH}$ at 6.0 (Fig. 9). Also, in a test using a fifteen minute reaction at $\mathrm{pH} 6.0$, the best enzyme activity occured at $55^{\circ} \mathrm{C}$ (Fig. 10). In Figs. 11 and 12 results of tests on stability of the enzyme are shown, indicating that the enzyme is stable at $\mathrm{pH}$ values between 5.0 and 9.5 and at temperatures less than $50^{\circ} \mathrm{C}$. The enzyme, however, was inactivated by several metallic ions; e.g. ferric, silver and mercuric ions.

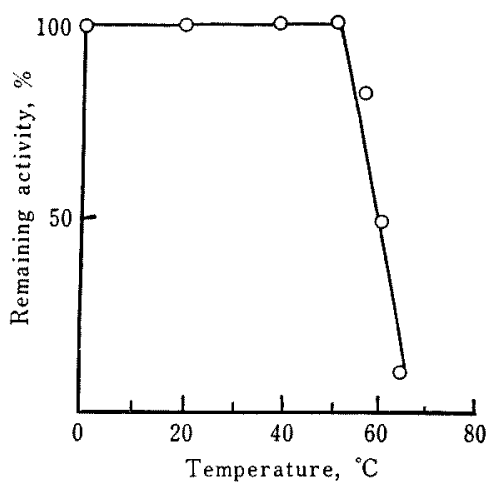

FIG. 12. Thermal Stability of Arabinogalactanase.

Heated for $15 \mathrm{~min}$ at the temperature indicated, M/20 Tris-HCI buffer, pH 7.5.

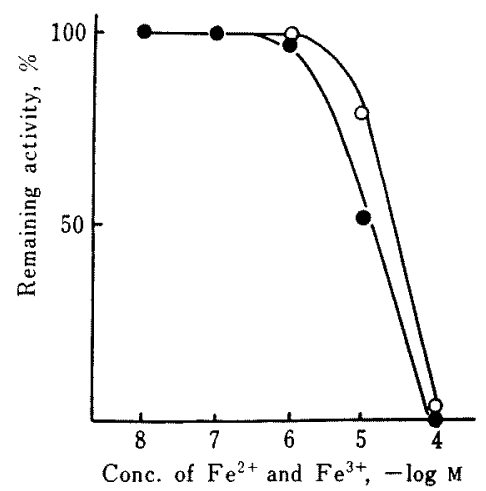

FIG. 13. Effects of Ferric and Ferrous Ions on the Stability of Arabinogalactanase.

Enzyme, buffered with $\mathrm{M} / 20, \mathrm{pH} 6.0 ; 40^{\circ} \mathrm{C}, 1 \mathrm{hr}$; $\mathrm{O}-\mathrm{O}, \mathrm{Fe}^{2+}\left(\mathrm{FeSO}_{4} \cdot 7 \mathrm{H}_{2} \mathrm{O}\right) ;-\longrightarrow, \mathrm{Fe}^{3+}\left(\mathrm{Fe}_{2}\left(\mathrm{SO}_{4}\right)_{3}\right.$. $9 \mathrm{H}_{2} \mathrm{O}$ ).

Effects of ferric and ferrous ions are shown in Fig. 13.

\section{Action on soybean- and coffee bean-arabino- galactan}

Figure 14 shows the pregressive curve due to hydrolysis of soybean arabinogalactan by the enzyme, indicating that the maximum hydrolysis degree is about $33 \%$. Also, paperchromatographic analyses of the hydrolysate of arabinogalactan revealed that the main 


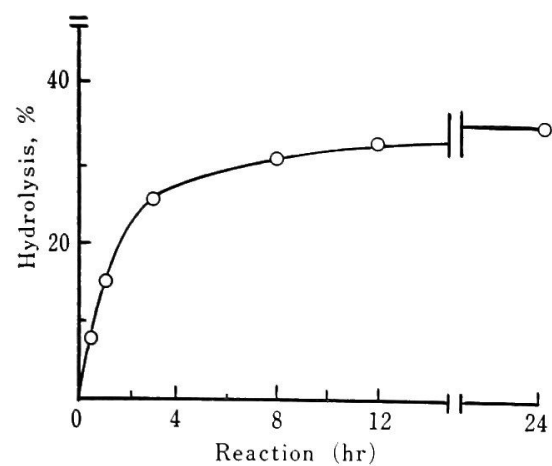

FIG. 14. Progressive Curve of Hydrolysis for Sovbean Arabinogalactan with Arabinogalactanase of Bacillus subtilis $\mathrm{K}-50$.

$6 \mathrm{ml}$ of $0.5 \%$ soybean arabinogalactan solution containing $\mathrm{M} / 50$ acetate buffer, $\mathrm{pH} 6.0$, reacted with $1 \mathrm{ml}$ of enzyme (activity, $1 \mathrm{U} / \mathrm{ml}$ ).

product was galactobiose $(\beta$-D-Gal $(1 \rightarrow 4)-\mathrm{D}-$ $\mathrm{Gal}$ ), as evidenced by the fact that on hydrolysis, the sugar increased its reducing power 1.8 fold, giving only galactose. In addition to galactobiose, small spots of free galactose and two oligosaccharides consisting of arabinose and galactose were also found in the hydrolysate (Fig. 15). However, no liberation of arabinose was observed there. The enzyme, on the other hand, showed no activity on arabinogalactan prepared from coffee beans whose main chain is known to consist of i-D-(1-3)-linked galactose ${ }^{3)}$ residues.

\section{DISCUSSION}

Formerly, we reported that the arabinogalactanase investigated here was inducibly formed by the bacterium. ${ }^{81}$ Morita $^{21}$ has proposed that arabinogalactan possesses the following structure:

\section{Araf 1-5 Araf $\frac{1}{\uparrow}$}

[-4 Galp 1-4 Galp 1-4 Galp 1-4 Galp 1- $]_{n}$,

8) S. Emi, T. Yamamoto and J. Fukumoto, Nippon Nogeikagaku Kaishi, 45, N 19 (1971).

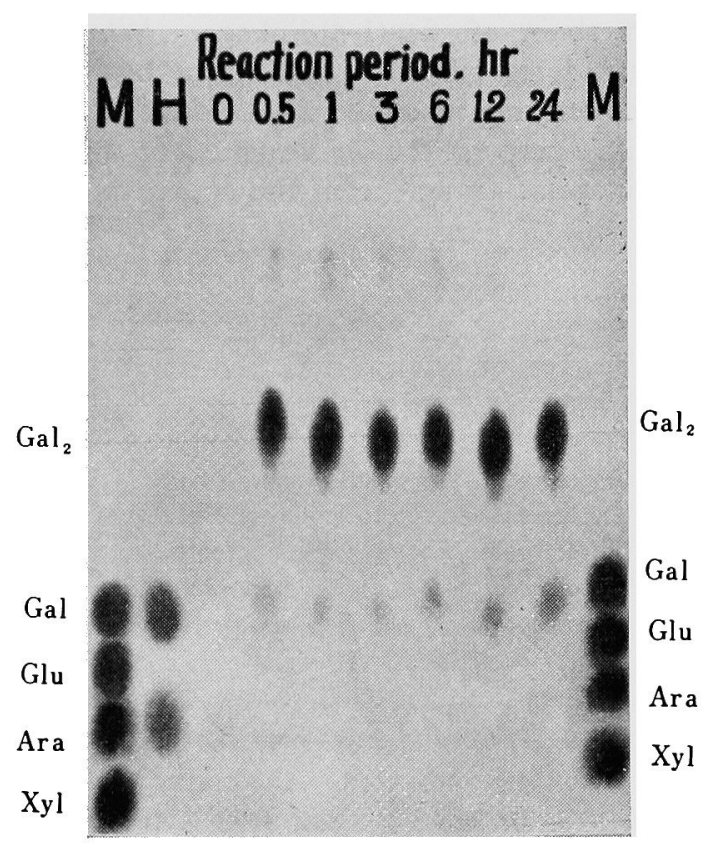

FIG. 15. Progressive Paper Chromatograms of the Hydrolysis of Soybean Arabinogalactan with the Arabinogalactanase of Bacillus subtilis $\mathrm{K}-50$.

M, markers: Xyl, xylose; Ara, arabinose; Glu, glucose; Gal, galactose; $\mathrm{Gal}_{2}$, galactobiose; $\mathrm{H}$, hydrolysate of soybean arabinogalactan with $1 \mathrm{~N}$ $\mathrm{HCl}, 100^{\circ} \mathrm{C}, 2 \mathrm{hr}$.

where galactan is the main chain by repeating the linkage of $-(1 \rightarrow 4) \beta$-D-galp $(1 \rightarrow 4)-$, and arabinose constitutes the side chain with the linkage of L-Araf (5-1) Araf at its $\mathrm{C}_{1}$ position to $\mathrm{C}_{3}$ of the galactose residue in the main chain. The average length of the arabinose chain is only two arabinose residues, linking with every fourth or fifth galactose residue in the main chain. As shown in Fig. 15, our enzyme produced galactobiose and small quantities of galactose from soybean arabinogalactan from the beginning of the enzyme reaction. The arabinose in the arabinogalactan was left as an oligoarabinogalactan after the enzyme reaction. This led to the conclusion that our enzyme hydrolyzes soybean arabinogaractan by attacking endowise the 
main chain of $\beta$-D-(1-4)-linkage. Why the which our enzyme hydrolyzes only the galacenzyme forms galactobiose from the beginning tose chain by end-wise attack.

of the enzyme reaction may be deduced from

Morita's proposal for the structure of soybean

Acknowledgement. This study was supported in arabinogalactan and from the action mode in part by a grant of Japan Foundation of Applied Enzymology. 